Малинаускас Ромуальдас Казимерович д-р пед. наук, профессор

Бальчюнас Паулюс магистрант

Литовский университет спорта г. Каунас, Литовская Республика

DOI $10.21661 / r-530497$

\title{
PECULIARITIES OF MENTAL TOUGHNESS AMONG CADET AND JUNIOR BASKETBALL PLAYERS
}

Аннотация: цель исследования - выявить особенности психической устойчивости среди баскетболистов - кадетов и юниоров. Для достижения этой иели в качестве методического инструментария был использован вопросник MTQ48. Результаты показали, что кадеты имеют более высокие оценки по шкалам «Реакиия на вызов» и «Контроль» по сравнению с баскетболистами-юниорами.

Ключевые слова: баскетболисты, психическая устойчивость, спортсмеHbl, cnopm.

Abstract: the aim of the study is to reveal the peculiarities of mental toughness among cadet and junior basketball players. To achieve this goal, the MTQ48 questionnaire (Mental Toughness Questionnaire 48) was used as a methodological toolkit. The results showed that cadets have higher scores on the "Reaction to the Challenge» and «Control» scales compared to junior players.

Keywords: basketball players, mental toughness, athletes, sport.

Introduction. There are many factors that affect the optimal level of performance in sports. One of the most important factors is individual mental ability (mental toughness) [1]. Performance psychology suggests that a certain level of sport performance depends on ability, motivation, and situational factors [1]. According to some 
experts, at least 50 percent of the athlete's success is due to mental toughness [2]. Mental toughness is the ability to withstand pressure, failures and recover from them in adequate and effective ways [1-2]. The presence of this factor leads to an advantage in sports, since this factor allows athletes to increase stability, concentration, self-confidence, as well as the ability to control themselves under stressful conditions during competitions [2]. Despite a large number of studies evaluating the mental toughness of athletes, only a few studies have been conducted with basketball players. Therefore, the essence of the scientific problem of research is the question: are there any statistically significant differences in the indicators of mental toughness among cadet and junior basketball players?

Materials and Methods. To achieve this goal, the MTQ48 questionnaire (Mental Toughness Questionnaire 48) [2] was used as an instrument, which measures four indicators of mental toughness: Control, Commitment, Challenge, and Confidence. For the current study, the MT48 was modified to ask the respondent to consider how they are in sport, as opposed to how they are generally, when responding to each item. The questionnaire for assessing indicators of mental toughness contains 48 statements that the participant must evaluate on a 5-point Likert scale. Total scores of the subscales are indicators of mental toughness. The results of the assessment of internal consistency for the MTQ48 questionnaire by the Cronbach $\alpha$ coefficient were high, and the coefficient $\alpha$ was 0.79 (for the subscales $0.76,0.79,0.82,0.81$, respectively) for the sample of the present study.

The selection of the study participants was carried out using the target sampling method. In our sample, we selected cadet and junior basketball players from the best teams in Vilnius and Kaunas. The sample included 107 basketball players, representing 4 cadet and 4 junior teams.

Results. The use of Student's $t$-test showed that statistically significant differences between the groups were not found when assessing some indicators of mental toughness, i.e., commitment and confidence (Table 1). 
Table 1

Indicators of mental toughness of young basketball players

\begin{tabular}{|l|c|c|c|}
\hline \multicolumn{1}{|c|}{$\begin{array}{c}\text { Indicators of mental } \\
\text { toughness }\end{array}$} & $\begin{array}{c}\text { Cadets } \\
\mathrm{n}_{1}=53\end{array}$ & $\begin{array}{c}\text { Juniors } \\
\mathrm{n}_{2}=54\end{array}$ & $t$ and $p$ \\
\hline Challenge & $3.69 \pm 0.62$ & $3.46 \pm 0.58$ & $1.98 ; p<0.05$ \\
\hline Commitment & $3.85 \pm 0.74$ & $3.83 \pm 0.78$ & $0.14 ; p>0.05$ \\
\hline Control (Emotions \& Life) & $3.49 \pm 0.48$ & $3.31 \pm 0.46$ & $1.98 ; p<0.05$ \\
\hline $\begin{array}{l}\text { Confidence (Ability } \\
\text { \& Interpersonal Interaction) }\end{array}$ & $3.71 \pm 0.53$ & $3.67 \pm 0.61$ & $0.36 ; p>0.05$ \\
\hline
\end{tabular}

However, it turned out that cadets, compared to junior basketball players have higher scores on the «Challenge» scale $(t(105)=1.98 ; p<0.05)$ and demonstrate higher scores on the «Control» indicator $(t(105)=1.98 ; p<0.05)$.

Discussion. It should be noted that the results obtained in this paper do not contradict the results of studies conducted by other scientists that junior players are more worried than cadets about events they don't expect or can't control [3-4].

Conclusion. Statistically significant differences were found in the indicators of mental toughness among cadet and junior basketball players: cadets have higher scores on the «Challenge» and «Control» scales compared to junior players.

\section{Список литературы}

1. Shoenfelt L.E. Mental Skills for Athletes: A Workbook for Competitive Success / E. L. Shoenfelt. - New York: Routledge, 2019. - Pp. 12-15.

2. Clough P.J. Mental toughness: The concept and its measurement / P.J. Clough, K. Earle, D. Sewell (Eds.) // Solutions in sport psychology. - London: Thompson Publishing, 2002. - Pp. 32-43.

3. Biglari S. The Comparison of Team and Individual Male Athletes, Mental Toughness at Different Levels of Skills / S. Biglari, A. Sanatkaran, S.M. Bahari [et al.] // International Journal of Basic Sciences and Applied Research. - 2015. №2. - Pp. 127-132.

4. Gucciardi D.F. Progressing Measurement in Mental Toughness / D.F. Gucciardi, S. Hanton, C.J. Mallett // Sport, Exercise, and Performance Psychology. - 2013. - №3. - Pp. 157-172. 
5. Zeiger J.S. Mental toughness latent profiles in endurance athletes / J.S. Zeiger, R.S. Zeiger // PLoS One. - 2018. - №13 (2). 